\title{
ANALISIS PROGRAM PERENCANAAN PENGANGGARAN RESPONSIF GENDER (Studi di Dinas Pemberdayaan Perempuan, Perlindungan Anak, Pengendalian Penduduk dan Keluarga Berencana Kota Batu Jawa Timur)
}

\author{
Dody Setyawan ${ }^{1}$, Firman Firdausi ${ }^{2}$, Sugeng Rusmiwari ${ }^{3}$ \\ $1,2,{ }^{3}$ Program Studi Ilmu Administrasi Negara, Fakultas Ilmu Sosial dan Ilmu Politik \\ Universitas Tribhuwana Tunggadewi Malang
}

Email:

dody.setyawan@unitri.ac.id

\begin{abstract}
This study aims to analyze the implementation of Gender Responsive Planning and Budgeting (PPRG) in Batu City. Analytical techniques use qualitative methods with a focus on general budgets, which incorporate gender assumptions and distribute budget allocations that take account of their gender impact. Data obtained through indepth interviews with purposive sampling on staff and employees who know and engage in budgeting. Furthermore, to study strategic policy document of Batu City, that is; RPJMD documents, RKPD documents and APBD documents by 2016. The results of research on gender responsive planning and budgeting process in the Regional Government Work Units (SKPD) have not been fully implemented due to the fact that the Regional Regulation (Perda) has not yet been established as the basis of Gender Equality Gender (PUG). There is no PUG Working Group at city and Focal Point level in SKPD. Budgeting also does not use gender analysis in the form of Gender Analysis Pathway (GAP) and Gender Budget Statement (GBS). In fact, these instruments become formal evidence of the existence of gender responsive planning and budgeting in Batu City Local Government
\end{abstract}

Key words: Policy Implementation, Gender Mainstreaming, and Gender Responsive Budget

\section{PENDAHULUAN}

Konferensi PBB untuk perempuan yang ke IV di Beijing tahun 1995 mengangkat isu Pengarusutamaan Gender (Gender Mainstreaming) dengan memetakan area kritis yang menjadi perhatian pemerintah dan masyarakat di seluruh dunia dalam mewujudkan kesetaraan gender. PUG didorong sebagai isu strategis yang harus diadopsi oleh PBB, pemerintah,dan organisasi yang relevan untuk memastikan bahwa rencana aksi diberbagai area kritis dapat dilaksanakan dengan efektif (Susiana, 2015:1).

Budaya di Indonesia umumnya masih menganut sistem patriarki. Budaya patriarki merupakan budaya dimana lelaki mempunyai kedudukan lebih tinggi dari wanita.Dalam budaya ini, ada perbedaan yang jelas mengenai tugas dan peranan wanita dan lelaki dalam kehidupan bermasyarakat, khususnya dalam keluarga. Laki-laki sebagai pemimpin atau kepala keluarga memiliki otoritas yang meliputi kontrol terhadap sumber daya ekonomi, dan suatu pembagian kerja secara seksual dalam keluarga.hal ini menyebabkan wanita memiliki akses yang lebih sedikit di sektor publik dibandingkan lelaki, (Ermaningsih \& Samawati, 2014: 111).

Sadar akan budaya tersebut dan dampaknya terhadap perempuan pada wilayah publik, maka Indonesia secara resmi mengadopsi PUG menjadi strategi pembangunan bidang pemberdayaan perempuan melalui Instruksi Presiden (Inpres) Nomor 9 Tahun 2000 tentang Pengarusutamaan Gender dalam Pembangunan Nasional. Selanjutnya menteri dalam negeri menerbitkan Peraturan Menteri Dalam Negeri (Permendagri) Nomor 67 tahun 2011 yang merupakan revisi dari Permendagri 
Nomor 15 tahun 2008 tentang Pedoman Pelaksanaan Pengarus Utamaan Gender (PUG) di Daerah.

Untuk mempercepat pelaksanaan PUG, juga telah dikeluarkan Surat Edaran tentang Strategi Nasional Percepatan Pengarusutamaan Gender melalui Perencanaan dan Penganggaran yang Responsif Gender (PPRG) pada tanggal 1 November 2012 yang dikeluarkan secara bersama-sama oleh Menteri Negara Perencanaan Pembangunan Nasional/ Kepala Badan Perencanaan Pembangunan Nasional, Menteri Keuangan, Menteri Dalam Negeri, dan Menteri Negara Pemberdayaan Perempuan dan Perlindungan Anak. Menindaklanjuti surat edaran tersebut, Menteri Dalam Negeri (Mendagri) telah mengeluarkan Surat Edaran No.050/6199/SJ tanggal 10 September 2013 (SE Mendagri) yang ditujukan kepada seluruh gubernur di Indonesia.

Pada tingkat pemerintah daerah, Pemerintah Provinsi Jawa Timur berkomitmen Pengarusutamaan Gender (PUG) masuk dalam kebijakan strategis dengan menerbitkan Peraturan Daerah Provinsi Jawa Timur Nomor 3 Tahun 2014 Tentang Rencana Pembangunan Jangka Menengah Daerah (RPJMD) Provinsi Jawa Timur Tahun 2014-2019. Salah Satu Strategi Pembangunan Jawa Timur Adalah Pengarusutamaan Gender. Untuk menjamin PUG dapat dilaksanakan pada seluruh jajaran pemerintahan kabupaten/kota di Jawa Timur, maka pemerintah Provinsi Jawa Timur menerbitkan Peraturan Gubernur Jawa Timur Nomor 66 Tahun 2013 Tentang Pedoman Pelaksanaan Pengarusutamaan Gender dalam Pembangunan Provinsi Jawa Timur.

Kota Batu salah satu Kota di Jawa Timur yang sedang berkembang pesat sebagai Kota Wisata. Jumlah penduduk Kota Batu pada akhir tahun 2015 adalah 214.969 jiwa, (https://batukota.bps.go.id), dengan rincian sebagai berikut Kecamatan Batu berjumlah 99.683 jiwa, Kecamatan Junrejo 53.408 jiwa, Kecamatan Bumiaji 61.878 jiwa. Jumlah penduduk laki-laki total berjumlah 108.473 jiwa, penduduk perempuan berjumlah 106.496 jiwa. Dengan jumlah tersebut antara penduduk laki-laki dan perempuan terpaut 1.977 jiwa wajar kalau pembangunan di Kota Batu harus mengedepankan pemberdayaan perempuan. Artinya perempuan harus memiliki akses yang sama baik dalam ekonomi, sosial, dan politik.

Pemberdayaan perempuan yang dimaksud sejalan dengan apa yang dikemukakan Gupta, bahwa:

Empowerment of women is essentially the process of up liftment of economic, social and political status of women, the traditionally underprivileged ones, in the society. It involves the building up of a society wherein in women can breathe without the fear of oppression, exploitation, apprehension, discrimination and the general feeling of persecution which goes with being a woman in a traditionally male dominated structure, (Gupta, 2017: 703).

Pemberdayaan terhadap kaum perempuan memerlukan perencanaan program, perencanaan anggaran yang responsif terhadap kepentingan perempuan. Keberadaan anggaran yang responsif terhadap perempuan ini bertujuan melindungi hak dan kepentingan perempuan, di samping melindungi terhadap diskriminasi, kekerasan, dan kekejaman dan juga untuk mencegah praktik yang tidak diinginkan secara sosial.

Oleh karena itu untuk menjamin kesetaraan bagi laki-laki dan perempuan dalam pembangunan memerlukan Perencanaan dan Penganggaran Responsif Gender (PPRG). Artikel ini fokus pada bagaimana implementasi Perencanaan dan Penganggaran Responsif Gender (PPRG) 
dalam Pembangunan di Kota Batu, problemproblem utama apa yang dihadapi oleh pemerintah Kota Batu dalam mewujudkan Anggaran Responsif Gender (ARG). Secara lebih rinci dijabarkan dalam pertanyaan: Bagaimana pelaksanaan kebijakan, program, dan kegiatan pembangunan yang terkait dengan PPRG; dan apa saja kendala yang dihadapi dalam penerapan konsep PPRG dan bagaimana solusi untuk mengatasi kendala tersebut menjadi diskusi dalam artikel ini.

\section{METODELOGI}

Data yang digunakan dalam tulisan ini merupakan hasil penelitian dengan pendekatan deskriptif kualitatif yang berlokasi di Kota Batu. Organisasi Perangkat Daerah (OPD) di Kota Batu dijadikan sebagai unit analisis. Sementara itu, informan ditetapkan secara purposive sampling, yakni orang-orang yang dipandang mengetahui dan terlibat dalam proses penyusunan anggaran responsive gender pada lembaga yang menjadi penggerak PPRG di Kota Batu, yaitu Badan Perencanaan Pembangunan, Penelitian dan Pengembangan Daerah (Bappelitbangda), Dinas Pemberdayaan Perempuan, Perlindungan Anak, Pengendalian Penduduk dan Keluarga Berencana (DP3AP2KB) dan Dinas Pendidikan.

Teknik pengumpulan data dilakukan melalui analisis dokumen, Focus Group Discussion (FGD) dan wawancara mendalam. Analisis dokumen dilakukan dengan menganalisis dokumen kebijakan strategis Kota Batu, yaitu; RPJMD 2012-2017,RKPD, APBD dan dokumen-dokumen laporan penyusunan statistik dan analisis gender. FGD dilakukan dengan mengundang sejumlah orang yang dipandang mengetahui tentang APBD dan Pengangaran Responsif Gender. Wawancara mendalam dilakukan dengan mewawancarai informan kunci yang bertanggung jawab dalam penganggaran dan penyusunan program responsif gender. Klarifikasi dan konfirmasi silang dilakukan untuk keabsahan data/ validitas data, (Creswell, 2010).

\section{HASIL DAN PEMBAHASAN}

\section{Implementasi PPRG di Badan Perencanaan Pembangunan, Penelitian, dan Pengembangan Daerah (Bappelitbangda) Kota Batu}

Pemerintah Provinsi Jawa Timur berkomitmen untuk mewujudkan program Pengarusutamaan Gender (PUG). Hal ini dapat dilihat dalam kebijakan strategis yang diterbitkan oleh Pemerintah Provinsi Jawa Timur melalui Peraturan Daerah Provinsi Jawa Timur Nomor 3 Tahun 2014 Tentang Rencana Pembangunan Jangka Menengah Daerah (RPJMD) Provinsi Jawa Timur Tahun 2014-2019.Salah Satu Strategi Pembangunan Jawa Timur Adalah Pengarusutamaan Gender. Untuk menjamin PUG dapat dilaksanakan pada seluruh jajaran pemerintahan kabupaten/ kota di Jawa Timur, maka pemerintah provinsi Jawa Timur menerbitkan Peraturan Gubernur Jawa Timur Nomor 66 Tahun 2013 Tentang Pedoman Pelaksanaan Pengarusutamaan Gender dalam Pembangunan Provinsi Jawa Timur.

Mengingat Kota Batu termasuk salah satu Kota di Jawa Timur yang sedang berkembang pesat sebagai Kota Wisata.Jumlah penduduk Kota Batu pada akhir tahun 2015 adalah 214.969 jiwa.Sementara jumlah penduduk perempuan diperkirakan sekitar 49,90 persen dari total penduduk. Dengan jumlah tersebut sudah seharusnya pembangunan di Kota Batu menerapkan prinsip-prinsip PPRG.

$$
\text { Razavi dan Miller }
$$

mendefinisikan PUG sebagai proses teknis dan politis yang membutuhkan perubahan pada kultur atau watak organisasi, tujuan, struktur, dan pengalokasian sumberdaya. Dengandemikian, PUG merupakan sebuah strategi, bukan tujuan. Strategi ini dirumuskan agar desain, implementasi, monitoring, dan 
evaluasi kebijakan dan program di seluruh ranah politik, ekonomi, sosial, dan budaya dapat terwujud. Sedangkan tujuan utamanya adalah mewujudkan keadilan gender. Untuk dapat melihat strategi PUG terlaksana dengan baik, Mengutip pendapat Miller dan Razavi (1998), dapat dilihat melalui tiga kategori anggaran sebagai berikut: Pertama; anggaran yang secara spesifik ditujukan pada kaum perempuan. Anggaran jenis ini misalnya saja bertajuk pemberian kredit kepada para pedagang kecil wanita. Kedua; anggaran pemerintah untuk belanja pegawainya, yang memungkinkan kesempatan yang sama pada pegawai laki-laki dan perempuan untuk menikmatinya. Anggaran yang ditujukan untuk membangun skema dana pensiun pegawai negeri, akan merupakan anggaran yang juga diakses oleh pegawai perempuan. Ketiga; angaran-anggaran umum, yang menyertakan asumsi gender dan mendistribusikanalokasi anggaran dengan memperhitungkan dampak gendernya.

Pada kajian dokumen RPJMD Kota Batu Tahun 2012-2017, perspektif gender dapat ditemukan di beberapa bagian.Pada Bab IV dokumen ini dicantumkan 87 sasaran pokok Rencana Pembangunan Jangka Panjang Daerah (RPJPD) 2005-2015 yang terlihat di dalamnya mengakomodir pemberdayaan perempuan dan anak serta kesetaraan gender. Dalam Bab IV ini juga dijelaskan bahwa proses penyusunan RPJMD ini pun tidak lepas dari pertimbangan akan perkembangan isu-isu strategis baik pada ranah Internasional, Nasional, dan Regional. Perwujudan kesetaraan gender dan pemberdayaan perempuan sendiri tergolong sebagai isu strategis yang perlu diperhatikan dalam proses perumusan kebijakan.

$$
\text { Prinsip proses perencanaan }
$$

pembangunan yang dikemukakan oleh Kepala Bidang Analisis, Pengendalian, dan Pelaporan Bappelitbangda Kota Batu, selama ini dilakukan dengan caraTop Down, Buttom Up, dan Partisipatif. Top down merupakan hal yang wajar dalam sebuah pemerintahan mengingat kepala daerah terpilih memiliki visi dan misi yang harus dijalankan. Sedangkan buttom up dilakukan melalui proses musyawarah perencanaan pembangunan (Musrenbang). Adapun partisipasi adalah usulan yang muncul baik dalam proses yang resmi seperti musrenbang, atau usulan dari kelompok masyarakat yang memang sesuai dengan isu strategis.

Bappelitbangda merupakan bagian dari Pokja PUG, bahkan merupakan koordinator dari kelompok ini.Maka tidak heran jika dalam dokumen Rencana Kerja Pembangunan Pemerintah Daerah (RKPD) TA 2016 Kota Batu, khususnya dalam urusan perencanaan pembangunan ditemukan sejumlah kegiatan yang terlihat ditujukan bagi kelancaran PUG.Kegiatan tersebut seperti penyusunan statistik dan analisis gender.Namun sangat disayangkan kedua program tersebut di atas tidak muncul dalam nomenklatur di Bappelitbangda maupun di Sekretariat Daerah. Artinya program itu ada dalam tahap RKPD, namun tidak disetujui dalam proses pengesahan di tingkat DPRD. Sehingga program itu tidak mendapatkan jatah anggaran dengan kata lain program itu dihapus.

Dengan memperhatikan uraian sebelumnya, dapat diketahui bahwa dalam APBD Kota Batu TA 2016 sejatinya terdapat anggaran-anggaran yang ditujukan bagi perempuan dengan harapan terwujudnya kesetaraan dan keadilan gender. Akan tetapi, hasil penelitian di Bappelitbangda anggaran tersebut tidaklah tersusun melalui proses penganggaran yang sesuai dengan peraturan perundang-undangan tentang pengarusutamaan gender (PUG). Berdasarkan Permendagri No. 67 Tahun 2011, proses penganggaran anggaran responsif gender seharusnya diinisiasi oleh sejumlah pihak, seperti Pokja PUG, Focal Point, serta melalui analisa gender dan GBS (Gender Budget Statement). Pada praktiknya, mekanisme ini 
tidak berjalan dengan maksimal.Alasannya adalah perencanaan yang dilakukan oleh Bappelitbangda belum menggunakan Analisis Gender berupa Gender Anaysis Pathway (GAP) dan juga belum menerapkan Gender Budget Statement (GBS).Seluruh program berasal dari turunan RPJMD, usulan pada musrenbang, dan usulan dari SKPD.Padahal GAP dan GBS adalah salah satu instrumen penting untuk menyusun anggaran yang responsif gender.

\section{Implementasi PPRG di Dinas Pemberdayaan Perempuan Perlindungan Anak, Pengendalian Penduduk dan Keluarga Berencana (DP3AP2KB) Kota Batu}

Dinas Pemberdayaan Perempuan

Perlindungan Anak, Pengendalian Penduduk dan Keluarga Berencana (DP3AP2KB) merupakan SKPD yang cukup banyak mencantumkan program serta kegiatan yang berhubungan dengan perwujudan kesetaraan gender. Namun demikian dalam proses penganggaran tersebut Dinas P3AP2KB bertugas mengajukan usulan prioritas kepada Bappelitbangda. Keputusan program serta kegiatan seperti apa yang akan disetujui berada sepenuhnya dalam kewenangan Bappelitbangda. Dengan kata lain, semua usulan program dari Dinas, keputusan akhir ada di Bappelitbangda, demikian yang disampaikan oleh informan Kepala Bidang Pemberdayaan Perempuan dan Perlindungan Anak, dalam wawancara mendalam.

$$
\text { Munculnya sejumlah program }
$$

berbasis gender di Dinas P3AP2KB itu tidak serta merta mencerminkan bahwa dinas ini menyusun program sesuai dengan instrumen dan ketentuan dari Permendagri Nomor 67 Tahun 2011. Karena dalam proses menyusun program tersebut mendasarkan pada hasil pertemuan dengan kelompok perempuan atau usulan organisasi kemasyarakatan melalui kegiatan non formal. Sementara dari hasil musrenbang tidak banyak memunculkan usulan-usulan yang mencerminkan keinginan masyarakat untuk mewujudkan kesetaraan gender. Mengingat perwakilan masyarakat yang hadir pada saat musrenbang tidak memahami isu-isu gender dan programprogram berbasis gender. Sehingga perwakilan masyarakat lebih banyak mengusulkan program-program yang bersifat fisik saja.

Pada Dinas Pemberdayaan Perempuan, Perlindungan Anak, Penanggulangan Penduduk dan Keluarga Berencana (DP3AP2KB) Kota Batu, ditemukan bahwa proses penganggaran responsif gender sebagaimana dimaksud dalam Permendagri No. 67 tahun 2011 belum terimplementasi secara maksimal. Meskipun berdasarkan SK Walikota Batu No. 180/81/KEP/422.102/2010 tentang pembentukan Kelompok Kerja (Pokja) PUG dan Focal Point telah dibentuk, namun demikian tidak ada program kerja yang disusun berdasarkan instrumen PPRG. Tidak adanya proses penganggaran yang menggunakan instrument GBS dan GAP, menyebabkan program yang ada merupakan kebijakan top down dan kepentingan prioritas berdasarkan pertimbangan politik. Diakuinya, analisa menggunakan GAP memang pernah dilakukan pada tahun 2013, akan tetapi tidak berlanjut pada tahun-tahun berikutnya dikarenakan dianggap bukan merupakan kebijakan strategis di Kota Batu.

Namun demikian, hasil kajian dokumen bahwa pernyataan telah dilaksanakannya GAP ini terbantahkan dengan dokumen yang ditunjukkan. Dalam dokumen yang dikaji, yaitu: laporan penyusunan statistik dan analisa gender (bidang politik dan ekonomi) tahun $2013 \mathrm{di}$ Kota Batu, yang dimaksud dengan GAP adalah analisa menggunakan model ProBA (Problem Based Approach). GAP dan ProBA sendiri merupakan instrument analisa gender yang bertujuan untuk mengetahui kesenjangan gender. Keduanya memang direkomendasikan untuk digunakan dalam proses penyusunan kebijakan di lembaga pemerintahan. Akan tetapi, berbeda dengan 
ProBA yang berangkat dari masalah kesenjangan atau situasi secara umum lalu kemudian menentukan kebijakan yang tepat untuk melakukan intervensi. Sementara GAP berangkat dari kebijakan yang telah dilaksanakan untuk meninjau kesenjangan gender dari segi akses, partispasi, kontrol, dan manfaat program atau kebijakan. Berdasarkan hasil analisa ini akan ditentukan rencana aksi yang tepat untuk mengatasi persoalan kesenjangan tersebut. Sehingga dapat dikatakan bahwa pemerintah Kota Batu belum menggunakan GAP sebagai instrument analisis gender.

Tidak adanya kemauan politik dan regulasi yang jelas dari pimpinan dalam hal ini pemerintah Kota Batu, menyebabkan penyusunan program tidak menggunakan prinsip-prinsip PPRG. Meskipun ada kegiatan sosialisasi mengenai PUG di tingkat provinsi, akan tetapi program PUG belum dapat diimplementasikan secara maksimal di Kota Batu karena tidak ditindaklanjuti menjadi sebuah keharusan dalam penyusunan program disetiap SKPD dan diintegrasikan oleh Bappelitbangda menjadi sebuah program berspektif gender.

\section{Implementasi PPRG di Dinas Pendidikan Kota Batu}

Dinas pendidikan merupakan satuan kerja perangkat daerah yang dinilai cukup untuk dilihat kinerjanya dalam perencanaan anggaran responsif gender berdasarkan dokumen-dokumen yang ada. Hal ini disebabkan jawaban-jawaban yang muncul dari kedua dinas lainnya menunjukkan pola yang sama (data jenuh). Ketiganya tidak memperoleh usulan-usulan berkaitan dengan kesetaraan gender dalam musrenbang, ketiganya juga tidak sepenuhnya memahami proses perencanaan anggaran responsif gender sebagaimana yang tertuang dalam peraturan perundang-undangan.

Dinas pendidikan merupakan satuan kerja perangkat daerah yang memiliki program dan kegiatan yang berkaitan dengan pemberdayaan perempuan. Dalam dokumen RPJMD Kota Batu Tahun Anggaran 2016, bidang pendidikan dengan menggunakan indikator Rasio Angka Partisipasi Murni menjadi salah satu hal yang ditargetkan dalam urusan pemberdayaan perempuan.Pencapaian target ini berada dalam tanggung jawab Dinas Pendidikan dan Dinas Pemberdayaan Perempuan.

Memperhatikan hasil dan pembahasan tersebut di atas, bahwa Perencanaan dan Penganggaran Responsif Gender sebagaimana diatur dalam Peraturan Menteri Dalam Negeri No. 67 tahun 2011 tidak berjalan maksimal. Berdasarkan peraturan ini seharusnya SKPD memperhatikan SK Walikota No. 180/81/KEP/422.102/2010 tentang pembentukan Kelompok Kerja (Pokja) PUG.Bappelitbangda sebagai ketua, Dinas P3AP2KB sebagai sekertaris, dan seluruh Kepala SKPD sebagai anggota.Pokja ini memiliki sejumlah tugas yang berfungsi menjamin berjalannya PUG dalam bentuk kebijakan, salah satunya dalam kebijakan penganggaran.Setiap kepala SKPD juga berkewajiban menetapkan Focal Point di setiap SKPD yang bertugas memfasilitasi perencanaan kebijakan dan anggaran SKPD agar responsif gender, belum terlaksana dalam tataran praktek perencanaan program.

\section{Hambatan Implementasi PPRG di Kota Batu}

Tidak terlaksananya PPRG secara maksimal di Kota Batu tidak dapat dilepaskan dari sejumlah kendala. Setidaknya terdapat sejumlah permasalahan yang menghambat implementasi PUG di pemerintah Kota Batu. Masalah-masalah tersebut dapat dikategorisasi menjadi tiga jenis pemasalahan. Pertama: faktor rotasi pegawai dan terputusnya transfer pengetahuan. Pergantian posisi pegawai atau rotasi sejatinya hal yang biasa terjadi di dalam sebuah organisasi. Termasuk di lingkungan lembaga pemerintahan daerah seperti Kota Batu. 
Namun rotasi ini justru menjadi hambatan bagi para pelaksana PUG karena mengakibatkan terputusnya koordinasi dan transfer pengetahuan yang sedang dijalankan. Baik Bappelitbangda maupun Dinas P3AP2KB sebagai sekertaris, secara langsung maupun tidak langsung terhambat kinerjanya disebabkan rotasi pegawai.Terbukti, meski pernah dilakukan analisis gender (dengan instrument ProBA) dan telah ada Pokja PUG serta Focal Point, pihak Bappelitbangda tidak mengetahui hal ini.

Pihak Dinas P3AP2KB sebagai sekertaris juga mengakui bahwa rotasi pegawai ini mengakibatkan terganggunya koordinasi di internal Pokja PUG dan Focal Point. Akhirnya hingga saat ini Pokja PUG tidak memiliki program kerja tersendiri. Akibat rotasi jabatan ini, pihak-pihak yang bertugas berganti dan mengakibatkan terputusnya transfer pengetahuan yang tengah dilakukan. Tanpa pemahaman yang baik, tentu akan mempersulit proses penyusunan rencana dalam upaya mewujudkan kesetaraan gender. Karena bukannya sibuk menyusun program, pihak yang baru terlibat sangat mungkin justru sibuk untuk mempelajari tentang PUG dan PPRG. Sementara sibuk belajar, program kerja untuk mewujudakan PUG harus disusun dan harus dilaksanakan. Fenomena Rotasi pegawai ini juga tidak dapat dilepaskan dari kebijakan kepala daerah dan pimpinan di setiap SKPD.

Kedua: faktor komitmen pimpinan institusi dan ketiadaan panduan di lingkup pemerintah Kota Batu. Lemahnya komitmen Institusi ini ditunjukkan dengan tidak ditaatinya sejumlah regulasi mengenai PUG yang telah ada. Sebagai contoh, meskipun GBS (Gender Budget Statement) telah lama ada untuk digunakan sebagai instrumen penyusunan anggaran, nyatanya hingga hari ini tidak digunakan oleh pemerintah Kota Batu dalam proses penyusunan anggarannya. Hal ini karena pimpinan pemerintah tidak mewajibkan SKPD atau penyusun anggaran untuk menggunakan instrumen ini.Lemahnya komitmen pimpinan terhadap PUG juga tercermin dari tidak kunjung disusunnya satu panduan bersama yang mengarahkan program PUG di Kota Batu.

Ketiadaan panduan ini berdampak pada tidak selarasnya program serta kegiatan pro perempuan yang disusun oleh SKPD. Salah satu faktor yang membuat SKPD-SKPD tidak menyusun anggaran responsif gender disebabkan tiadanya perintah lisan maupun tertulis dari pimpinan. Hanya dengan keberadaan perintah pimpinan saja perencanaan dan penganggaran responsif gender dapat terlaksana di tingkat SKPD. Ketergantungan para pelaksana terhadap perintah pimpinan memang merupakan hal wajar mengingat sistem kepemimpinan di lembaga eksekutif bersifat satu komando. Bila pimpinan telah memerintahkan suatu hal atau menerbitkan suatu kebijakan, maka itu akan berpengaruh terhadap keputusan serta kebijakan yang diimplementasikan oleh para pegawai di bawahnya. Sebaliknya, jika tidak ada perintah maupun kebijakan atau regulasi yang mengatur, maka sangat sulit bagi Aparatur Sipil Negara (ASN), khususnya pada pemerintahan daerah untuk mengambil keputusan.

Ketiga: faktor perencanaan RPJMD yang tidak maksimal. Meskipun RPJMD telah mencantumkan sejumlah program dan kegiatan pro perempuan akan tetapi indikator yang disediakan tindak selaras dengan indikator yang ditunjukkan dalam indikator kinerja daerah. Sebagai contoh, dalam target capaian pada program peningkatan peran serta dan kesetaraan jender dalam pembangunan terdapat Rasio Angka Partispasi Murni peserta didik perempuan terhadap lakilaki. Sementara itu dalam indikator kinerja daerah tidak ditemukan adanya Rasio Angka Partispasi Murni peserta didik perempuan terhadap laki-laki sebagai indikasi keberhasilan daerah. Target prosentase 
perempuan yang disasar oleh program dan kegiatan juga tergolong lebih kecil dibanding dengan laki-laki. Hal ini diakui karena dalam proses penyusunan RPJMD 2012-2017 tidak maksimal.

Memperhatikan ketiga faktor tersebut di atas, terlihat bahwa individu pelaksana program merupakan salah satu bagian penting yang menentukan berjalan atau tidaknya suatu program dan kegiatan. Karena, individu inilah yang akan memilih untuk bertindak atau tidak bertindak, melaksanakan atau tidak melaksanakan sebuah kegiatan dan program. Menurut Friedman (2013), setidaknya terdapat tiga faktor yang mengakibatkan seorang individu menaati atau tidak mentaati sebuah aturan, dalam hal ini aturan mengenai perancanaan dan penganggaran responsif gender.

Faktor untung-rugi (cost and benefit). Seseorang akan bertindak patuh atau tidak patuh terhadap suatu aturan dengan mempertimbangkan keuntungan serta kerugian dari setiap tindakan. Dalam hal pelaksanaan Permendagri No. 67 Tahun 2011, Walikota Batu atau Kepala-Kepala SKPD akan memperkirakan keuntungan yang akan diperolehnya bila melaksanakan aturan tersebut. Begitu juga Ia akan memperkirakan kerugian yang didapat bila tidak melaksanakan norma dalam aturan tersebut. Bila Ia merasa keuntungan yang didapatkan dengan melaksanakan Permendagri No. 67 Tahun 2011 cukup layak untuk diperoleh, maka sangat mungkin Ia akan melaksanakan aturan tersebut. Meskipun, sebaliknya bila dengan tidak melaksanakan aturan tersebut tidak ada kerugian yang didapat, maka sangat mungkin Ia tidak akan melaksanakan norma tentang perencanaan dan penganggaran responsif gender.

Seseorang akan memilih untuk melakukan tindakan hukum (patuh atau tidak patuh) dipengaruhi oleh rekan-rekan sebaya (peer group) atau rekan dalam kelompoknya. Dalam konteks pelaksanaan Permendagri No.
67 Tahun 2017, bila banyak SKPD tidak melaksanakannya, maka sangat besar kemungkinan SKPD lainnya juga tidak menerapkan aturan ini.

Hal yang sangat berpengaruh terhadap pilihan tindakan hukum seseorang ialah kesadaran. Meskipun tidak ada keuntungan serta tidak banyak pihak yang melaksanakan aturan tersebut, bila seseorang telah sadar akan pentingnya pelaksanaan aturan terkait, maka Ia pasti memilih untuk mengimplementasikan norma dalam peraturan. Begitu pula sebaliknya, sebanyak apapun kerugian yang akan diperoleh bila tidak menjalankan aturan dan sebanyak apapun SKPD yang melaksanakan peraturan tersebut, namun bila tidak ada kesadaran, sangat sulit berharap suatu aturan berjalan dengan maksimal (Friedman: 2013).

\section{PENUTUP}

Hasil penelitian ini menunjukkan tidak berjalannya Pokja PUG di tingkat Pemerintah Daerah dan Focal Point di tingkat SKPD. Penyusunan anggaran juga tidak menggunakan analisa gender dalam bentuk GAP (Gender Analysis Pathway) dan GBS (Gender Budget Statement). Padahal, instrument-instrument tersebut yang akan menjadi bukti formil adanya perencanaan dan penganggaran responsif gender pada pemerintah daerah.Setidaknya terdapat tiga faktor yang menjadi kendala dalam implementasi PPRG di Kota Batu.Pertama, Faktor Rotasi Pegawai dan Terputusnya Transfer Pengetahuan.Kedua, Faktor Komitmen Pimpinan Institusi dan Ketiadaan Panduan di Lingkup Pemerintah Kota Batu.Ketiga, Faktor Perencanaan RPJMD yang kurang maksimal.

Namun demikian keberadaan SK Walikota No. 180/81/KEP/422.102/2010 tentang pembentukan Kelompok Kerja (Pokja) PUG, setidaknya dimasa yang akan datang Perencanaan Penganggaran Responsif Gender menjadi sebuah keniscayaan. 


\section{DAFTAR PUSTAKA}

Creswell, J. W. (2010). Research Design: Pendekatan Kualitatif, Kuantitatif, dan Mixed (Terjemahan: Ahmad Fawaid). Yogyakarta: Pustaka Pelajar.

Ernaningsih, W., \& Samawati, P. (2014). Pengaruh Budaya Patriaki terhadap Perceraian. Malang: Penerbit Tunggal Mandiri.

Friedman, L. M. (2013). Sistem Hukum Perspektif Ilmu Sosial. . Bandung: Nusa Media.

Gupta, A. (2017). Women Representation in Local Bodies and Gender Sensitive Budget. . Journal of Commerce $\mathcal{E}$ Management Thought (Vol. 8-4) , 703-714.

Miller, C., \& S., R. (1998). Gender Analysis: Alternative Paradigms. Retrieved from http:/ / www.undp.org/gender

Setyawan, D. (2011). Peran Civil Society sebagai Pressure Group Dalam Perumusan Kebijakan Publik di Kota Malang. Jurnal Reformasi, FISIP, Universitas Tribhuwana Tunggadewi .

Susiana, S. (2015). Penerapan Konsep Perencanaan dan Penganggaran Responsif Gender (PPRG) dalam Pembangunan Daerah (Studi di Provinsi Papua dan Provinsi Daerah Istimewa Yogyakarta. Jakarta: Pusat Pengkajian, Pengolahan Data dan Informasi (P3DI) Sekretariat Jenderal DPR RI.

\section{PeraturanPerundang-undangan}

Undang-undang No. 7 Tahun 1984 tentang Pengesahan Konvensi mengenai Penghapusan Segala Bentuk Diskriminasi terhadapWanita.
Instruksi Presiden Nomor 9 Tahun 2000 tentang Pengarusutamaan Gender dalam Pembangunan Nasional;

Keputusan Menteri Dalam Negeri Nomor 132 Tahun 2003 tentang Pedoman Umum Pelaksanaan Pengarusutamaan Gender dalam Pembangunan di Daerah.

Peraturan Menteri Dalam Negeri Nomor 15 Tahun 2008 tentangPedoman Umum Pelaksanaan PengarusutamaanGender dalamPembangunandi Daerah.

Peraturan Daerah (Perda) Kota Batu Nomer 5 Tahun 2016 tentang Pembentukan dan Susunan Perangkat Daerah;

Peraturan Walikota Batu Nomor 89 Tahun 2016 tentang Kedudukan, Susunan Organisasi, Uraian Tugas dan Fungsi, serta Tata Kerja Badan Perencanaan Pembangunan, Penelitian, dan Pengembangan Daerah Kota Batu.

SK

$$
\text { Walikota }
$$

Batu No. 180/81/KEP/422.102/2010tentang pembentukan Kelompok Kerja (Pokja) PUG dan Focal Point

Peraturan Gubernur Jawa Timur Nomor 66 Tahun 2013 Tentang Pedoman Pelaksanaan Pengarusutamaan Gender dalam Pembangunan Provinsi Jawa Timur.

Sumber lain:

1. https://batukota.bps.go.id/ data jumlah penduduk berdasarkan kecamatan di Kota Batu 2016. 